\title{
COUNSELING APPLICATION FOR CHARACTER EDUCATION
}

Hakim Ratih Luftikasari

Faculty of Education,

University of Muhammadiyah Jakarta, Indonesia
Received: October 29, 2021

Accepted: December 17, 2021

Published: January 17, 2022

Corresponding Authors:

hakimratih@darunnajah.ac.id

DOI: $10.53947 /$ tspj.v1i2.177

\begin{abstract}
Technology has developed in advance and helped us provide so many tools to achieve the result that we earn. So many applications were created to help the student understand the lesson clearly, but our mission as educators is to improve their knowledge and hone their character. This study is mainly concerned with building an application that helps students solve their adolescent problems and shape their personalities to be noble humans.
\end{abstract}

Keywords: Counseling Application, Student Character, Adolescence, Personality, Deterioration of morality

\section{Introduction}

During today's progress, what is often forgotten is that education advances intelligence and builds the character of future generations of young people. The problems that occur in many developing countries today are the decline in morals and the problem of low interest in learning in adolescent students.

Adolescence is often known as the period of rebellion. At this time, a child who has just gone through puberty often shows various emotional fluctuations, withdrawing from the family, and experiencing many problems, either at home, school, or in the home environment or the circle of friends. Juvenile delinquency at this time, as is widely reported in various media, has been said to exceed the reasonable limit. Many teenagers and minors are familiar with cigarettes, drugs, free sex, theft brawl, and are involved in many other criminal acts that deviate from the norms that apply in society and deal with the law (Unayah \& Sabarisman, 2015).

Can technology help us to solve this? Especially when the pandemic hit the world, students' screen time jumped significantly because of distance learning and boredom. They must always stay at home to avoid the danger of being infected. Results from the research before, 74 respondents were obtained during four weeks. The duration of screen time significantly correlates with the total behavior problems in children $(p=0.024)$. Conclusion; The Correlation is the increase of screen time beyond the recommended. Increasing the screen time beyond the recommended 
duration can cause various behavioral problems in children, such as emotional problems, behavior, and hyperactivity (Simanjutak, 2020).

Another negative impact of prolonged exposure to the internet is that students are contaminated with harmful content that can damage their minds. Not to mention the time they spend playing games and looking for entertainment outside of their study assignments make the possibility of their addiction to the internet more likely to increase.

Parents' difficulties supervising their children while surfing the internet make their control significantly more minor and loose. Therefore, students in their teens need a companion who can make discussion friends for the various problems they face apart from their parents to become mature individuals.

\section{Research Method}

This study uses the ADDIE research and development method, which will analyze the need for product development in a guidance and counseling application that targets adolescent students and the product's feasibility and requirements. Then design how to design the concept and content in the product. The conceptual framework that has been made previously will be continued into a product realization that is ready to be implemented. The application will be implemented in certain schools, and continuous evaluation will continue to be carried out.

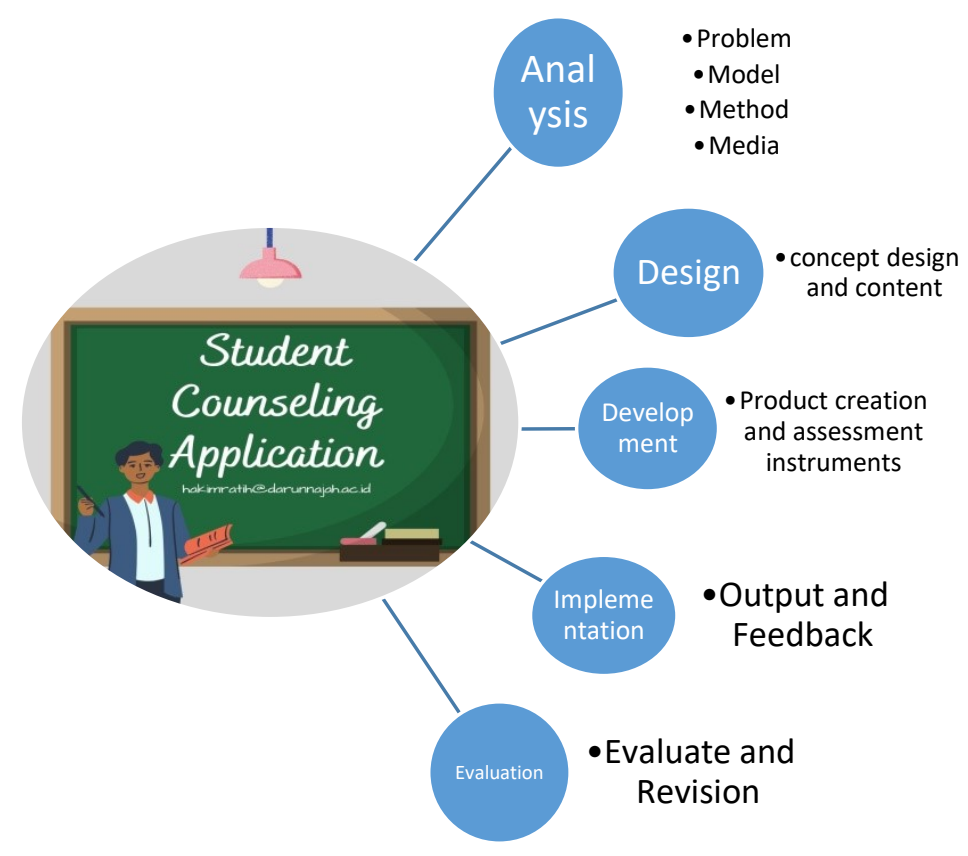

Figure 1 ADDIE METHOD ON STUDENT COUNSELING APPLICATION

\section{Discussion and Analysis}

The main problem that will be studied is how to make an application that can be used in a student environment to guide them in solving their problems. Adolescent students have widely used several online psychology applications. Unfortunately, 
due to the large number of users queuing up for free consultations and limited human resources (professional psychologists) in the end, the application users are neglected and cannot continue counseling sessions.

The application model that will be used will take the form of a website and platform application that will be made similar to social media. This author's idea application platform has the advantage of various supporting features that will undoubtedly be very useful for teenage students. Personal chats are a forum for counseling. The application that the author is designing also provides talent honing features, meaningful stories, and, most importantly, a consultation room. There are also application support features in podcasts about related material. There is also a daily treasury quotes feature containing wise words that will be updated every day. This platform will also be equipped with video material support regarding self-love, character development, and mental health, which professional psychologists and available counseling teachers will fill. This application will use the basics of Islamic psychology. Then the material presented will refer to the primary source, namely the Quran and the Prophet's Hadith.

Students in the adolescent phase are experiencing inner turmoil, which causes them not to like being advised in a patronizing way. That is why we designed this application with a friendly, relaxed, and fun concept. The content that we will develop is based on three main things. The first is a meaningful story. In this feature, users will find various stories about the problems they usually experience. By reading the story, it is hoped that they can take life lessons and directions to solve their problems. There are also daily quotes that they can use as pearls of wisdom that will cheer up their day. We will provide podcasts and audiobooks with the same theme for students who tend to study audio.

The second and most important part is the consultation room. In this feature, we allow users to hide their names as anonymous to consult more freely with counselors. The consultation method will use methods such as sending letters. So the counselors will have time to reply to consultation messages from clients according to the order of entry first, first come, first serve. If there is an emergency case that must be handled directly, we will work with the guidance and counseling teachers at the school.

The third part is the features to hone talent. Teenage students like to show off what they are doing. Showing their talents can also increase their confidence in their daily lives. Especially with the existence of a particular stage with grouping according to specific talents. By adopting the social media model, this feature also allows them to have discussions in the comments column about sharing impressions and tips for their shared talents.

For this app, we purposely separated them by gender. Because the problems faced by teenage boys and girls are very different and their interests are different. By separating users by gender, this application can be implemented in special schools such as Islamic boarding schools. With this separation, it is hoped that the user evaluation process will become easier to measure and redevelop. The name of this app will be "AKRABI," based on Arabic language, ققرب, which means close. We named 
it hoping that this application will be their close friend in dealing with various life problems and help them help themselves. AKRABI also means friendly in English. So, they can make this application like social media that they usually use every day more positively. For boys, when logging into the application, it will be guided by a system called AKRA, and for girls, it will be guided by a system called RABI.

\section{Conclusion and Recommendation}

Why do we think this app will work? Because besides, this application is used as a counseling tool that aims to help teenage students through critical times and help them solve the problems they are facing. In addition to the problem of a heavy learning burden, they also still have to face social problems that shape them into civilized human beings. This app will give them a shoulder to lean on and an ear to hear their complaints in a fun way without being patronizing.

A suggestion to consider is whether this app will be paid for or not. Because some experts need to be paid, this application requires a lot of money. However, this application will be implemented during the trial and research period at the Darunnajah Islamic Boarding School Jakarta, which already has qualified facilities and alumni who can be used as partners to create content.

\section{References}

Simanjutak, I. dan S. (2020). Peningkatan Trend Screentime selama Pandemi Covid 19 dan Efeknya pada Perilaku Anak Increased Trend Screentime during the Covid-19 Pandemic and Its Effects on Children's Behavior. Profesional Islam, 18(2), 109-115.

Unayah, N., \& Sabarisman, M. (2015). Fenomena Kenakalan Remaja Dan Kriminalitas: THE PHENOMENON OF JUVENILE DELINQUENCY AND CRIMINALITY. Sosio Informa, 2 No 2(2), 74-88. 